\title{
Hamleś Skolimowskiego jako parodia
}

Doprawdy dziwny film. Ekscentryczny - z mocno podkreślonym efektem agresywnej obcości i anormalności ukazanego świata - a przecież swojski, tutejszy, niemal reporterski w warstwie realiów. Z drugiej strony, przenikliwie diagnozujący sytuację polityczną, w jakiej powstał, zadziwiająco dojrzały, pozbawiony złudzeń i niemal proroczy w swoim gorzkim pesymizmie co do perspektyw nadchodzącego jutra. „Chciałem robić kino, które oświeci, dotrze do serc i umysłów” - powie po latach jego autor.

Hamleś Jerzego Skolimowskiego jest etiudą studencką nakręconą w roku 1960

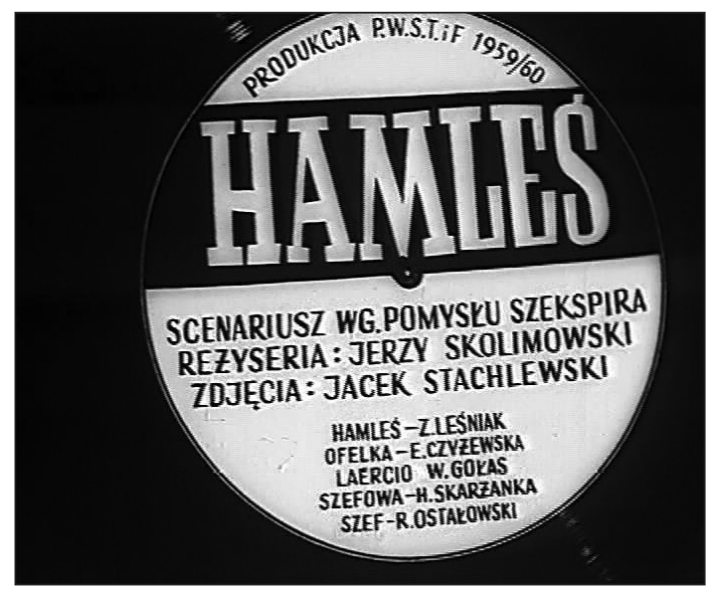
przez młodego, zaledwie 22-letniego reżysera. I powiedzmy sobie od razu: gdyby nie znaczny margines wolności wypowiedzi, jaki w owym czasie oferowała swoim studentom łódzka Szkoła Filmowa, ta krótkometrażowa fabuła nigdy nie zostałaby nakręcona, więcej: „nie miałaby prawa” powstać w ramach systemu produkcji filmowej PRL. Młody adept reżyserii bezbłędnie zagospodarował i wykorzystał w tym projekcie ostatni moment względnej swobody, która na pewien czas stała się udziałem nie tylko artystów, ale też milionów Polaków po Październiku' 56.

Trzeba mieć nie lada tupet, żeby zaadaptować Szekspirowski arcydramat na trwającą na ekranie mniej niż dziesięć minut krótkometrażową etiudę fabularną. I jeszcze większy tupet, by zmienić Hamleta w alegoryczną parodię. Czyżby? Z parodią to prawda, ale Szekspir jako komentator spraw toczących się w Związku Radzieckim i w krajach tzw. obozu socjalistycznego stanowi temat zasługujący na osobne studium. Już z samych wystawień Hamleta w powojennym teatrze polskim dałoby się ułożyć pasjonującą opowieść o wolności, zniewoleniu, cenzurze i kolejnych zmaganiach artystów, by na przekór okolicznościom gorzka alegoria okazała się wykładnią tego, co aktualnie przeżywa jednostka i społeczeństwo.

Jeśli za synonim osobowości hamletycznej uznać chwiejność i wahanie, ówczesny student reżyserii wywiązał się z tego niełatwego zadania inscenizacyjnego celująco. Już w pierwszej scenie, otwierającej 
etiudę, wprowadza na ekran temat wahania: nie tylko każąc dwojgu swoich bohaterów kiwać się na wysoko zawieszonej huśtawce, ale także przechodząc do następnej sceny wahadłowym ujęciem kamery (prowadzonej z ręki) - spojrzeniem skierowanym na matkę (Szefową). Dźwiękowym ekwiwalentem motywu wahania staje się wielokrotna repetycja zacinającej się płyty gramofonowej. Warto przy tym zwrócić uwagę na - typowy dla całej twórczości filmowej Jerzego Skolimowskiego - dosłowny, somatyczny wręcz sposób zamiany abstrakcyjnego pojęcia, jakim jest wahanie, na jego dosłowny, sensualnie przekazany widzowi metaforyczny ekwiwalent.

Z kolei, kluczowy dla konstrukcji dramatu Szekspira chwyt „teatru w teatrze” zamienia Skolimowski na happening rozgrywający się przed kamerą. Jego Hamleś nie ma być jednak klasycznym Hamletem. To Hamlet Skolimowskiego „według pomysłu Szekspira”. Wszystko, co pojawia się w tym filmie: od poszczególnych zdarzeń i epizodów, poprzez galerię postaci, aż do rekwizytów, kostiumów i scenerii, naznaczone zostało przez autora świadomie zaaranżowanym refleksem umowności oglądanego przedstawienia. Spróbujmy przyjrzeć się temu bliżej, wychodząc z założenia, iż charakterystyczny prześmiewczy sposób ukazania świata przedstawionego stanowi integralny element parodyjności Hamlesia.

Postaci, czyli obsada

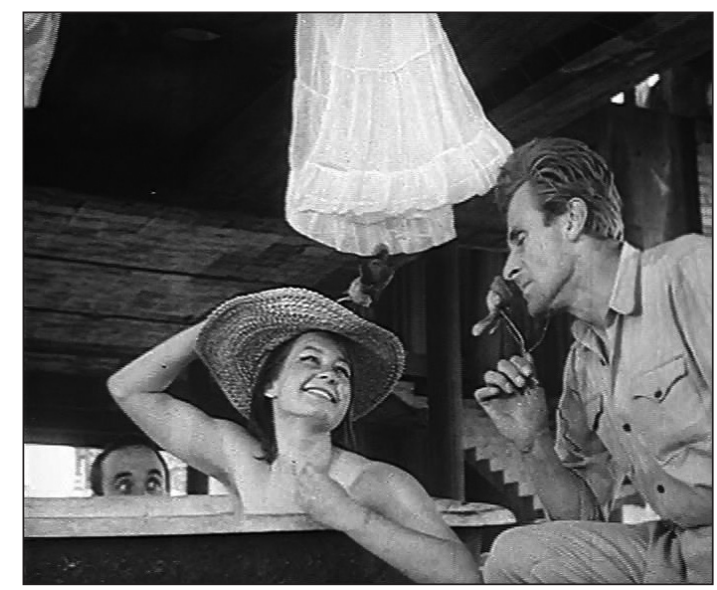

Skolimowski bezceremonialnie zmienia Szekspira: przekłada Hamleta „na nasze”, dostosowuje go i przykrawa do własnych potrzeb. Dlatego, choć jego bohater weźmie do ręki czaszkę, nie usłyszymy nawet linijki ze słynnego monologu. Adaptator-parodysta bezceremonialnie bierze z pierwowzoru tylko to, co jest mu potrzebne i niezbędne do wykreowania jego własnej opowieści. Opowieści, która rozgrywa się w peerelowskim tu i teraz.

W Hamlesiu pojawia się zaledwie sześć postaci. Każda z nich jako persona dramatis ma swój Szekspirowski odpowiednik, ale pierwowzór nadaje jej tylko konieczne minimum teatralno-literackiej tożsamości. Postawna Królowa (gra ją Hanna Skarżanka) nazywana jest Szefową. Skolimowski pokazuje ją jako kobietę władczą, dojrzałą i wyemancypowaną: w czarnej bluzce z wyciętym dekoltem i stroju, jaki nosiły wtedy na przykład barmanki. U jej boku mocny mężczyzna, on, czyli Szef (Ryszard Ostałowski). Zgodnie z intrygą Hamleta, to oni dwoje zawiążą perfidny spisek przeciw księciu, sami padając na końcu jego ofiarą.

A skoro już o „dworze” i panujących na nim mowa... Zeswojszczenie pierwowzoru polega w Hamlesiu na wyrazistym, wręcz ostentacyjnym obniżeniu stylu. Dwór królewski staje się u Skolimowskiego czymś na kształt stołecznej meliny na świeżym powie- 
trzu. Ostro się tutaj pije. Co takiego się pije? Zgodnie z ówczesnym obyczajem, rzecz jasna, trąbi się czystą wódkę (bywa, że z butelki po oranżadzie). Są też piękne i nietrudne kobiety. W chwili gdy oglądamy scenę kąpielową z udziałem nagiej Ofelii (gra ją Elżbieta Czyżewska, ówczesna muza reżysera), narrator śpiewa:

Ofelka musi zapoznać się z wodą

Żeby wypełnić wskazania Szekspira.

Gdy goły pępek jest podstawą świata

Chyli się przed nim najwspanialsza lira.

Para królewska w Hamlesiu to Szefowa

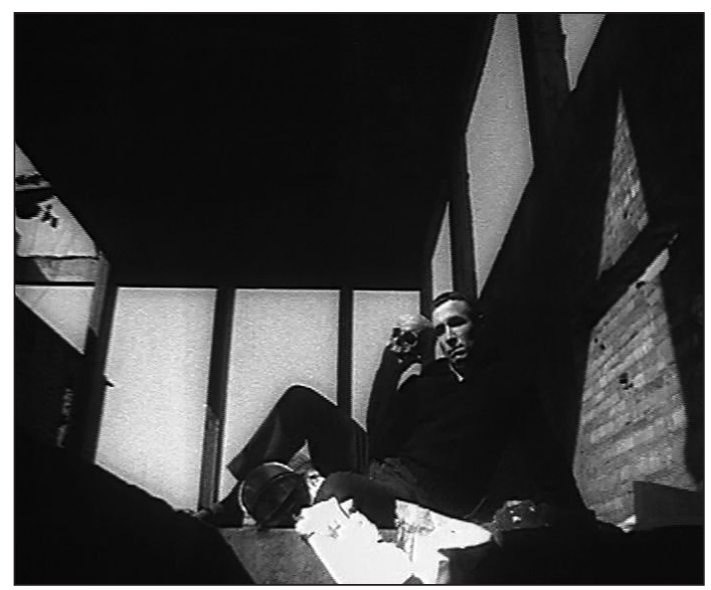
i Szef. Oni tu rządzą. Szekspirowska Ofelia w ozdobionym kwiatami kapeluszu na głowie przeobraża się w emanującą sex appealem Ofelcię. Jest jeszcze nierozgarnięty dryblas Laertes (Wiesław Gołas), zwany w filmie Laerciem, który podobnie jak jego teatralny pierwowzór zostaje ślepym narzędziem dworskiej intrygi i zbrodni.

Reżyser w parodystyczny sposób ukazuje swoich bohaterów. Tadeusz Sobolewski, trafnie w moim przekonaniu, zdefiniował ten osobliwy ansambl jako „szemrane, artystyczne towarzystwo”[1]. Imiona bohaterów dramatu, a właściwie ich przekształcenia, okazują się znaczące. Dotyczy to nie tylko Ofelki (w analogii do Felki etc.) czy Laercia (Miecia, Stefcia, Gucia itp.), ale przede wszystkim tytułowego Hamlesia (w nawiązaniu do Lesia, Olesia, kolesia, obwiesia itd.).

Hamleś - to swojski koleś Hamlet, przynależny do żyjącego z dnia na dzień rozpitego światka warszawskiej inteligencji końca lat 50. Obsadzając w tej roli aktora kojarzonego przede wszystkim z komedią i kabaretem, Zdzisława Leśniaka, Skolimowski świadomie czyni go figurą na poły slapstickową, śmieszną i niepoważną, zamieniając dramat w parodię.

Dramat jest, dramat jest, ... amat jest...

Jeśli ktoś ciągle się waha

I jeśli ręce w polityce macza

I gdy mu miłość we wszystkim przeszkadza

Dramat jest, dramat jest, ... amat jest...

- brzmią pierwsze słowa ballady.

Kariera ballady w życiu artystycznym ZSRR i krajów satelickich wydaje się być dość zagadkowym fenomenem socjokulturowym dopóty, Dlaczego ballada? dopóki nie zauważymy, iż zwiększona częstotliwość pojawiania się i popularność tego gatunku - zarówno w piosence, jak i w filmie - wiąże się ściśle z mechanizmami reagowania cenzury i próbami jej ominięcia

[1] T. Sobolewski, Outsider Skolimowski, „Kino” 1996, nr 11. 
przez artystów. Gatunek ten stał się jedną z artystycznych odmian języka ezopowego, która zyskała z czasem wysoki stopień atrakcyjności i subtelności wyrazu. Ballada estradowa (Okudżawa, Przybora, Dymny, Młynarski, Chyła, Kaczmarski i wielu innych), a także ballada filmowa (Kluba, Paradżanow, Szulkin, Riazanow et consortes) przez dziesiątki lat pozwalała autorom dotykać - w poetyckim kostiumie i lirycznej formie - spraw i tematów uznawanych za mniej lub bardziej niecenzuralne.

Motywy zbrodni są jak zawsze błahe

Za to sposoby niezwykle wymyślne

Zdradziecka broń oraz zdradziecki napój

- śpiewa narrator Hamlesia.

A kiedy zbliża się kulminacyjny moment spisku, dodaje, opowiadając po swojemu Szekspirowski dramat:

Straszliwa szykuje się draka...

...draka się szykuje straszliwa...

Bicie po gębie i oko za oko.

Polityczne mistyfikacje wokół.

I zdrada godzi znów w niewinnych ludzi.

Balladowość w kulturze i sztuce PRL nie była wyrazem chwilowej mody, lecz swoistym sposobem ekspresji artystycznej, której charakterystyczny wyznacznik stanowi wymuszona cenzurą eufemizacja przekazu. Skolimowski nie posługuje się jednak tylko konwencją ballady. Zestawiona z parodią, balladowość Hamlesia nadaje temu utworowi charakter w dwójnasób subwersywny. Podtekstowość i sztuczność parodii łączy się tutaj i przenika z liryczno-epicko-dramatycznym charakterem i równie umowną sztucznością balladowej opowieści.

To nie dzieło przypadku, lecz skutek oddziaływania konkretnych historycznych okoliczności na wyobraźnię artystów, że prozaicy, filmowcy, a także poeci (rewelacyjna w swym kształcie językowym Ballada od rymu Mirona Białoszewskiego) sięgnęli po balladę w czasach odwrotu władzy od względnie liberalnego kursu politycznego. Od pierwszej do ostatniej sceny Hamlesia mamy do czynienia z autorską grą cudzym tekstem (mowa oczywiście o parodystycznie traktowanym przez reżysera Hamlecie). I jednocześnie - z aluzyjnymi odniesieniami do aktualnej sytuacji, umiejętnie przebranymi i ukrytymi pod kostiumem ballady.

Nazwisko Białoszewskiego zostało tu wywołane nieprzypadkowo. Młody Skolimowski fascynował się jego twórczością: zarówno Teatrem Osobnym, jak i poezją. Studencka etiuda Hamleś pełnymi garściami czerpie z poetyki farmazonu[2], którą tak kunsztownie i przewrotnie wykorzystał poeta w datowanej na ten sam czas Balladzie od rymu, będącej wtedy kwintesencją awangardowej sztuki poetyckiej

[2] Zob. M. Hendrykowski, Farmazon. Studium z genologii polskiego kina popularnego, „Kwartalnik Filmowy" nr 56, 2006. 
w Polsce. Dotyczy to zwłaszcza pomysłu, by stworzyć w ten sposób balladę kulawą i skrzywioną, jakby zwichniętą, która nie może i nie chce wyzbyć się czynnika parodystycznego, dążąc po swojemu do osiągnięcia zamierzonego celu.

Rozpatrywany od strony gatunkowej, Hamleś pozostaje bardzo szczególnym, jeśli nie wręcz unikatowym, przypadkiem takiej właśnie filmowej ballady, ze względu na wspomniane połączenie z parodią i wynikający z tego nośnego połączenia wydźwięk krytyczny. Intensywnie podkreślana, nieustanna obecność elementów parodii w etiudzie Skolimowskiego, a zwłaszcza tkwiąca w niej przekora i ładunek prześmiewczy, miała w sobie coś z bezpardonowej, bezczelnie śmiałej kontestacji.

Betonowe schody, betonowe stropy konstrukcji bez ścian. Coś niegdyś nowego, co zamieniło się w porzuconą bezpańską ruderę. Wszędzie kurz i prozaiczne akcesoria (wanna, syfon, hełm strażacki, wyciąg murarski) pozostawione w nieładzie przez ekipę budowlańców. Dzięki przemyślnej aranżacji inscenizacyjno-operatorskiej Jerzego Skolimowskiego i Jacka Stachlewskiego naturalna sceneria betonowej konstrukcji jakiegoś wielopiętrowego budynku stołecznego $\mathrm{w}$ budowie zamieniła się przed kamerą $\mathrm{w}$ wyrafinowaną plastycznie scenografię.

Efektem ubocznym, który się odfotografował, stała się aura porzucenia i pozostawienia samemu sobie tego opuszczonego miejsca. Przymiotnik „ekscentryczny” znaczy tu tyle, co wyrzucony poza centrum, zgodnie z etymologią wyrazu (łac. ex - 'z', 'spoza' + gr. héntron 'środek koła'). Właśnie w takiej opuszczonej peryferyjnej przestrzeni przebywają przez cały czas bohaterowie.

W obskurnym, byle jakim i prowizorycznym świecie, jaki został zaprezentowany w tym filmie, ludzie nie mają wiele do roboty i dysponują mnóstwem wolnego czasu. Nie znaczy to bynajmniej, że wyobrażone w nim życie jest przyjemne. Wprost przeciwnie, od pierwszej do ostatniej sceny wyczuwa się wrogość i podskórne napięcie, umiejętnie podsycane przez reżysera. Hamleś nie znosi Laercia, Laercio nie cierpi Hamlesia. Szefowa szczuje ich na siebie, zajmując przed walką pozycję trenera w narożniku bokserskim, który przygotowuje zawodnika do starcia.

Młody Skolimowski dobrze radzi sobie z dramaturgią i mikrodramaturgią krótkiego metrażu. Ciekawy motyw przewodni analizowanej etiudy stanowi seria intrygujących repetycji („dramat jest..., ....amat jest..., ... amat jest”, „straszliwa szykuje się draka... draka szykuje się straszliwa...”, „reszta jest milczeniem......eszta jest milczeniem... ...eszta jest milczeniem..." etc.).

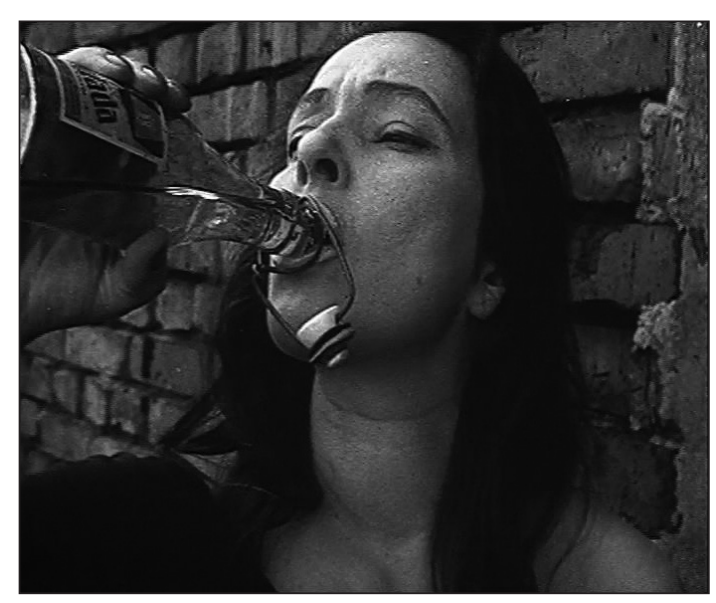

Scenografia

i scenografia dźwiękowa 


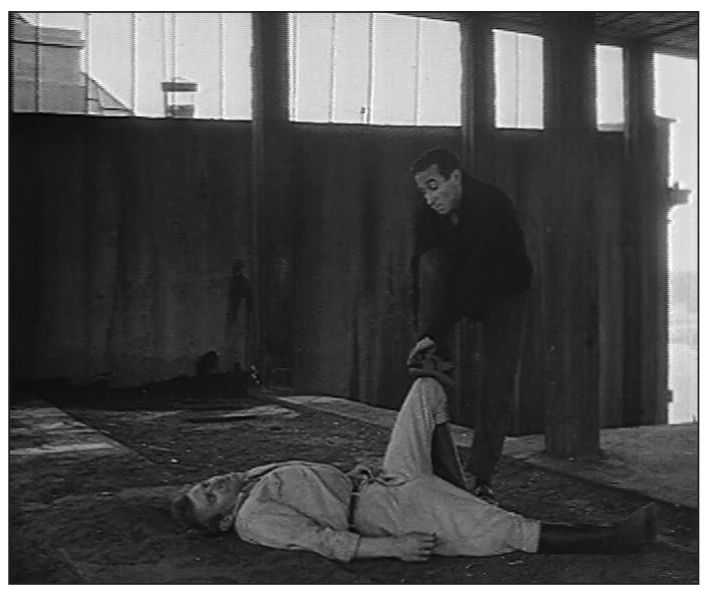

Pomysłowo rozwiązana czołówka składa się tylko z jednej planszy, pełniącej funkcję etykiety na płycie gramofonowej. Motyw starej płyty pojawia się w filmie kilkakrotnie. Nie chodzi tylko o to, że Szefowa i Szef siedzą przy patefonie z tubą, słuchając ballady z zacinającej się płyty, co umieszcza cytowane wyżej powtórzenia „wewnątrz" rozgrywających się wydarzeń: w porządku synchronii warstwy diegetycznej. Idzie o coś więcej. Natrętne repetycje pełnią $\mathrm{w}$ tym filmie istotną funkcję kompozycyjną. Zamykają bowiem ekranową przestrzeń, w której egzystują bohaterowie, stając się w końcu wyrazem uwięzienia: czymś w rodzaju skumulowanej obsesji. Nieudolne refreny ballady okazują się przemyślnie użytymi elementami scenografii dźwiękowej, co czyni Jerzego Skolimowskiego pełnym oryginalnej inwencji odkrywcą i prekursorem sonorystyki w kinie polskim. Scenografii i scenerii - zarówno wizualnej, jak i audialnej (dla przykładu: sugestywny efekt skrzypiącej huśtawki) - przypada w tym filmie eksponowana rola czynnika kreującego bezczas i immanentną nijakość ekranowego świata. Hamleś niczym Ubu Król („rzecz dzieje się w Polsce, czyli nigdzie”) - rozgrywa się w świecie niedookreślonym. A przecież - dzięki znanym adresatowi swojskim realiom (na przykład tytułom ówczesnych czasopism) - jego historia daje się odnieść do konkretnie istniejącej rzeczywistości. Aby odczytać autorskie przesłanie etiudy, trzeba jednak najpierw odkryć jej głębszy podtekst.

Podtekst, czyli subwersywność
Subwersywność filmu Skolimowskiego ma charakter semantycznie złożony. Z jednej strony, reżyser bazuje na sztuce Szekspira, z drugiej - wywołuje aktualny kontekst, ściśle związany ze zmianą kursu politycznego władz partyjnych PRL, które otrząsnąwszy się z czerwcowo-październikowego szoku, na powrót sięgają w grze prowadzonej ze społeczeństwem po wypróbowane, zamordystyczne metody działania. Jeden klucz odczytania nie istnieje tu bez drugiego. Dopiero połączenie ich w procesie odbioru otwiera interpretatorowi możliwość dotarcia do głębszych pokładów znaczeniowych, jakie kryje w sobie ta - od początku do końca z całą konsekwencją nastrojona parodystycznie studencka etiuda.

Do analizowanego i interpretowanego przez nas obrazu warto jeszcze dodać pewien kontekst obyczajowy. Socjalizm w permanentnej budowie tzw. zrębów ustroju ulegał na co dzień osobliwemu zagospodarowaniu przez przedstawicieli różnych warstw społecznych, w tym tzw. wolnych zawodów i ludzi marginesu. Zjawiali się oni, uprawiając rozmaite formy życia towarzyskiego, tam, gdzie nie było czuć natrętnej obecności ustroju. I właśnie o ten „margines”, tyle że metaforycznie rozumiany, tutaj chodzi. 
Bohaterowie Hamlesia są gronem kilkorga indywiduów z marginesu i jednocześnie mikrospołecznością ludzi na marginesie, egzystujących z dala od głównego nurtu życia. Wybór scenerii okazuje się nieprzypadkowy i znaczący, rzutuje nie tylko na charakterystykę postaci, ale i na generalną wymowę całego filmu.

Szkolna etiuda Hamleś z 1960 roku - pisze Tadeusz Sobolewski - mogłaby służyć za alegorię procesu „przykręcania śruby”. W ruderze bez ścian, jakich wiele straszyło jeszcze wtedy w Warszawie, „draka szykuje się straszliwa”. Do słów ballady śpiewanej miejskim slangiem, rozgrywa się tragedia Hamleta, w obrazach jak z amatorskiego teatru[3].

Amatorski aspekt inscenizacji oraz gry aktorskiej w Hamlesiu nie jest pochodną nieumiejętności zespołu twórców filmu i jego reżysera, lecz świadomie obraną i konsekwentnie przeprowadzoną przez całość metodą artystycznego wyrazu. Świat przedstawiony (czytaj: rzeczywistość PRL) okazuje się światem byle jakim: niedorobionym, tymczasowym, cierpiącym na chroniczną prowizorkę. Jego bezdomna (brak drzwi i ścian) prowizoryczność dotyczy nie tylko warstwy materialnej, lecz przenika także głęboko w wizerunek wszystkich bez wyjątku bohaterów. Efekt ten daje o sobie znać wprost w ich ekranowych zachowaniach i sposobie bycia. Nieprzypadkowo Szefowa, Szef, Laercio czy tytułowy Hamleś stale przesiadują, snują się bądź - co znamienne - polegują w jakimś przypadkowym miejscu. Robią jednak oprócz tego coś jeszcze, a mianowicie czytają...

Pokaż mi, co czytasz, a powiem ci, kim jesteś - głosi znane nie od dzisiaj powiedzenie. Zauważmy, iż w spustoszonym krajobrazie, jaki prezentuje nam ten film, nie istnieją w ogóle książki. Natomiast przemyślnie zaaranżowany rekwizyt scenerii w etiudzie Skolimowskiego - pierwszorzędnie ważny, jak się za chwilę okaże - stanowią walające się wszędzie gazety. Bohaterowie Hamlesia całą szóstką są bowiem czytelnikami prasy. Nie jakiejkolwiek jednak, tylko tej, którą przydzielił im reżyser. Z jednej strony, tworzą oni skazaną na siebie mikro. zbiorowość, z drugiej - każde z nich czyta co innego, kierując się własnymi upodobaniami. Odpowiednio dobrany tytuł prasowy staje się dzięki temu znaczącym atrybutem, aluzyjnie przypisanym charakterystyce i wizerunkowi wewnętrznemu danej postaci.

Zacznijmy od Szefa, który - zmierzając do pozbycia się Hamlesia i uzdrowienia tą drogą niezdrowej sytuacji - okazuje się czytel-

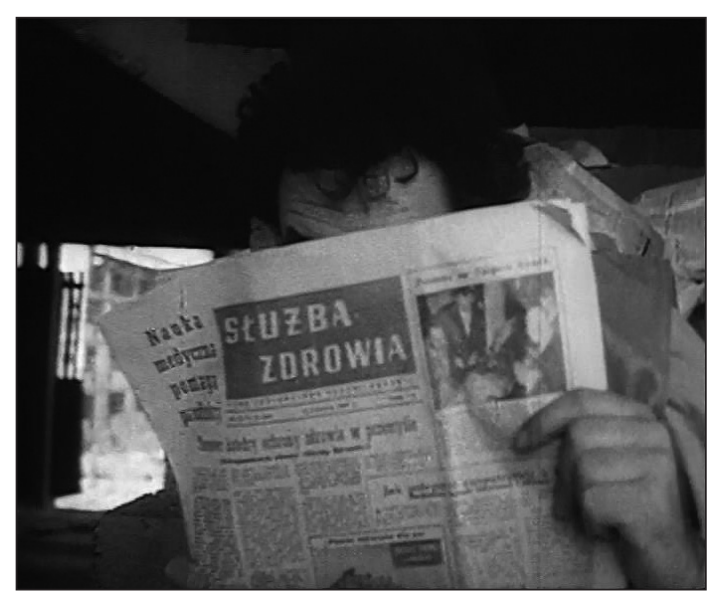

[3] T. Sobolewski, Skolimowski w pułapce polskości, w: Jerzy Skolimowski, red. M. Żydowicz, Camerimage, Toruń 1998, cyt. s. 48. 


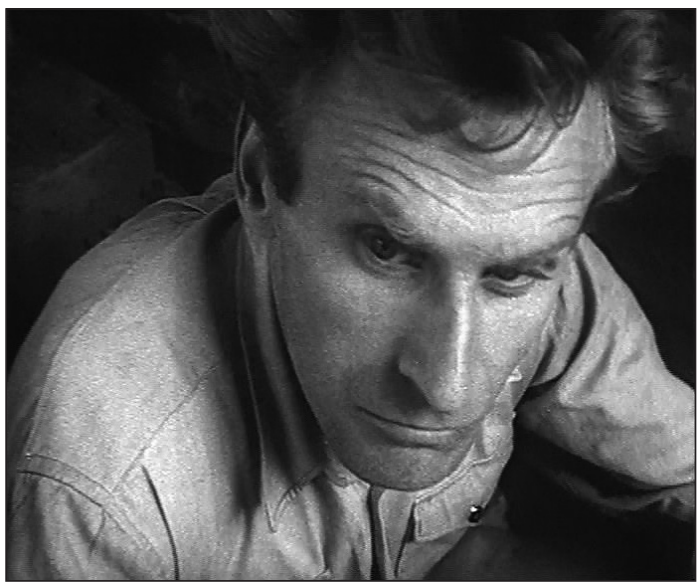

nikiem wymownego tytułu „Służba Zdrowia”. Szefowa z kolei, jak przystało na stuprocentową kobietę PRL, preferuje niezwykle popularny w tamtych czasach poradnikowy periodyk dla polskich gospodyń i pań domu - tygodnik pod tytułem „Przyjaciółka”. Dziarski chłopak Laercio kultywuje krzepę oraz zamiłowanie do militariów i wojskowego stylu bycia. Świadczy o tym jego ekranowy strój: wojskowy krój koszuli, bryczesy i oficerki. Nic dziwnego zatem, iż siedząc na schodach, trzyma w ręku egzemplarz ilustrowanego magazynu „Żołnierz Polski”, będącego organem prasowym Głównego Zarządu Politycznego Wojska Polskiego oraz Zarządu Głównego Ligi Przyjaciół Żołnierza, późniejszej Ligi Obrony Kraju[4].

A co czyta Hamleś? To wyjaśnia się już w pierwszym ujęciu filmu. Tytułowy bohater, huśtając się z Ofelką na murarskim wyciągu, okazuje się namiętnym czytelnikiem tygodnika „Polityka”. Przypomnijmy w tym miejscu, iż kilka miesięcy przedtem, gdy po wakacjach roku 1957 zamknięto niepokorny i nieprawomyślny tygodnik „Po prostu”, w kioskach PRL pojawiło się nowe czasopismo pod tytułem „Polityka” - początkowo przyjęte niechętnie, bo utożsamiane z antypaździernikowym

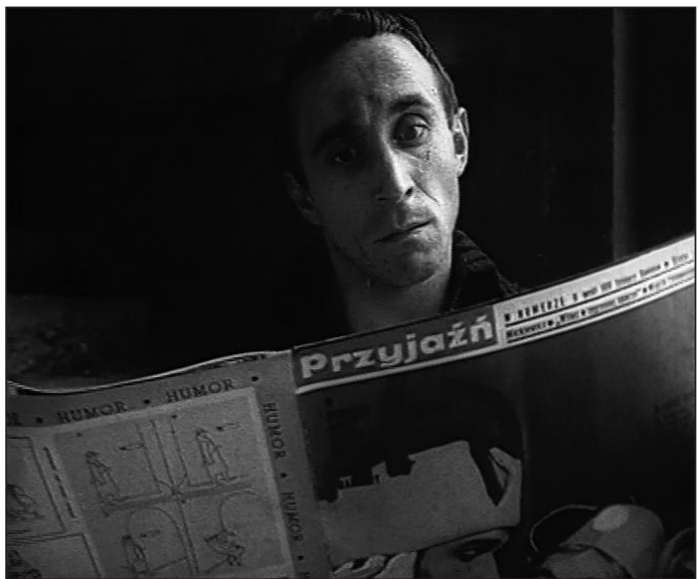
kursem partii. Wkrótce jednak atmosfera wokół nowego tygodnika zmieniła się. Odkąd w roku 1958 redaktorem naczelnym został Mieczysław F. Rakowski, „Politykę” zaczęto utożsamiać z reformatorskimi tendencjami pewnej części aparatu partyjnego, co wydatnie zwiększyło liczbę jej czytelników.

Hamleś, nałogowy czytelnik polskiej prasy, nie ogranicza się jednak wyłącznie do lektury „Polityki”. Pod koniec filmu widzimy, że trzyma w ręku diametralnie odmienny od niej tygodnik „Przyjaźń”, organ Towarzystwa Przyjaźni Polsko-Radzieckiej. Ta zmiana jednego tytułu na drugi - dzisiaj być może mniej czytelna - była wówczas zmianą niezmiernie wymowną. Po gorzkiej lekcji, jaką otrzymał od życia, Hamleś przestaje hamletyzować: uznając nowy porządek za oczywisty i jedynie możliwy. Jak do tego dochodzi?

Wszystko zmienia się, gdy na scenę/budowę wkracza w mundurze milicyjnym Fortynbras, w którego roli reżyser wymownie obsadził samego siebie.

[4] W czasie gdy Skolimowski kręcił Hamlesia, redaktorem naczelnym „Żołnierza Polskiego” był Stanisław
Ryszard Dobrowolski - znany z serwilistycznych zachowań wobec władzy „poeta z robotniczej Woli”. 
Oto nadchodzi chwiejąc się puenta.

Zdrowie i przyjaźń - wszystko to pozorem.

On tu najwyższym tej prasy cenzorem

I sytuacji

I ludzi też.

Reszta jest milczeniem...

...eszta jest milczeniem...

...eszta jest milczeniem

- kończy swą ponurą balladę narrator.

Wymiana jednych tytułów prasowych na drugie okazuje się faktem wielorako znaczącym. Autor Hamlesia posłużył się tutaj alegorycznym skrótem. Oto zwycięski Fortynbras wkracza triumfalnie na budowę, na-

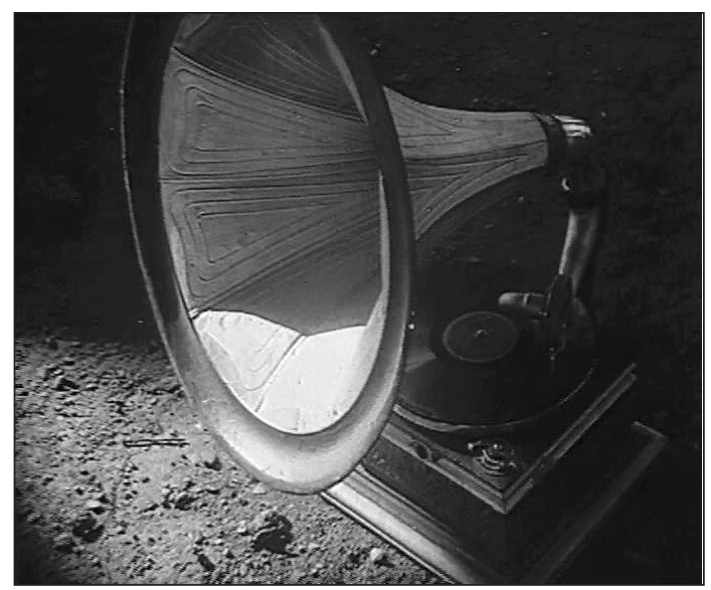
trafia na Ofelkę czytającą w wannie, zabiera jej numer ilustrowanego pisma „Nowa Wieś” i wyjmuje z kabury (sic!) coś innego do czytania. Etiuda Hamleś, o czym była mowa na początku tego studium, zawiera w sobie przenikliwą diagnozę Polski końca lat 50.: „, sytuacji i ludzi też”, by posłużyć się raz jeszcze przywołanym przed chwilą cytatem.

Parodia Skolimowskiego ma typowy dla tej formy komunikatu wymiar obsesyjno-kompulsywny (określenie Dona Fredericksena). Chorzy ludzie w chorym systemie i chorej rzeczywistości zostają ukazani bez złudzeń. Ukazani przez artystę takimi, jakimi są, co pozwala widzowi odkryć prawdę o własnym świecie i poczuć, iż świat ten jest atrapą świata rzeczywistego. Okazuje się on niby-światem, czymś z gruntu nierealnym i sztucznie narzuconym jako forma zniewolenia człowieka i jego umysłu. Tych nieco ponad dziewięć minut studenckiego filmu, jaki nakręcił wówczas 22-letni Skolimowski, należy dzisiaj do kanonu naszej sztuki tamtego okresu jako przekaz artystyczny o niezwykłej doniosłości. 


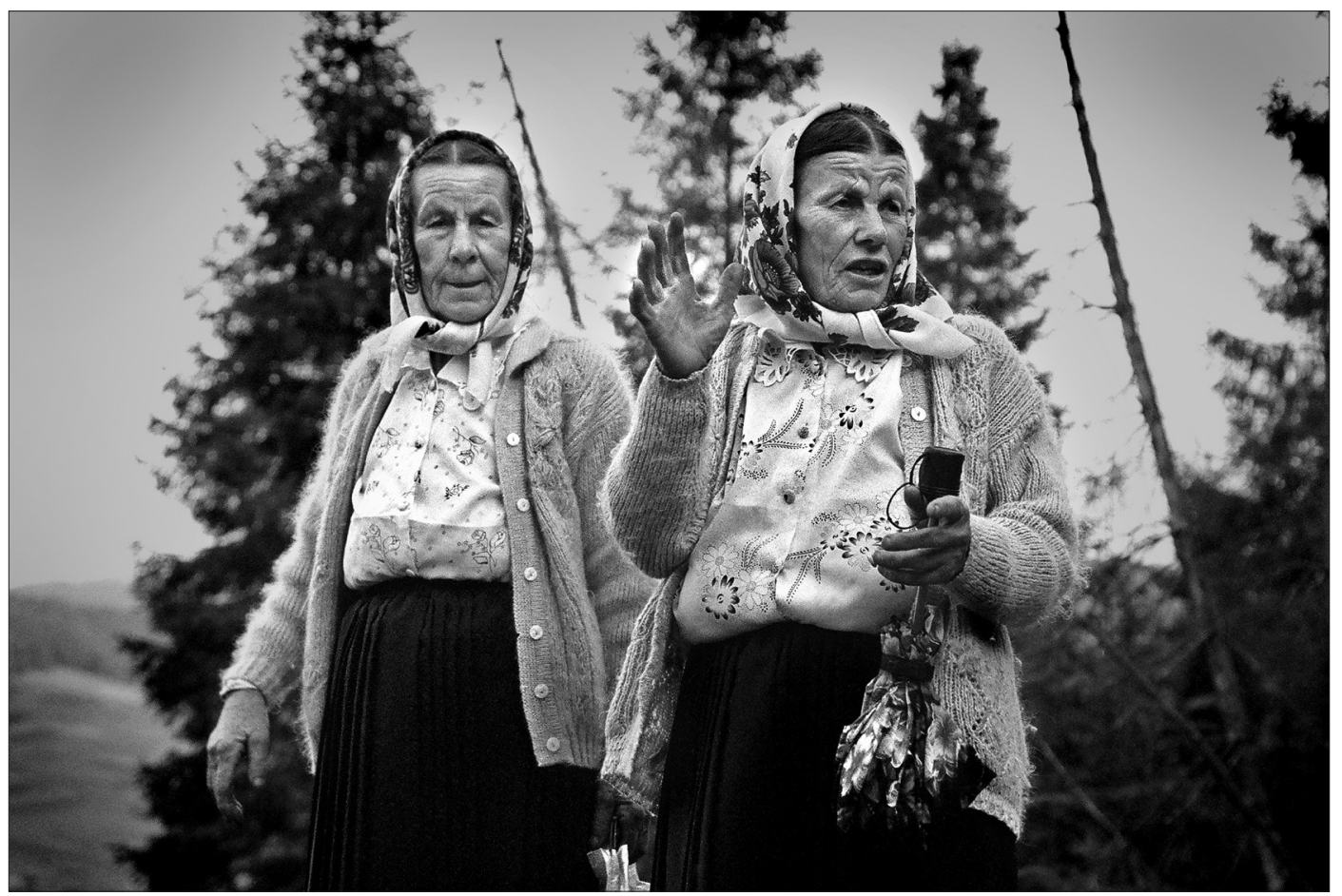

Fot. Maciej Łabudzki 